Sains Malaysiana 50(1)(2021): 35-43

http://dx.doi.org/10.17576/jsm-2021-5001-04

\title{
Pengesanan dan Pencirian Leptospira spp. pada Haiwan Liar dan Persekitaran di Pusat Pemuliharaan ex situ
}

(Detection and Characterization of Leptospira spp. in Wildlife and the Environment at the ex situ Conservation Centre)

\author{
Nadia Aqilla Shamsusah, Badrul Munir Md Zain, Sabapathy Dharmalingam, Fairuz Amran \& Hani- \\ KARTINI AGUSTAR*
}

\begin{abstract}
ABSTRAK
Leptospirosis ialah penyakit berjangkit yang disebabkan oleh bakteria Leptospira yang boleh menjangkiti manusia dan haiwan. Kajian ini dijalankan bagi mengenal pasti jangkitan leptospirosis yang berkitar antara orang utan, roden dan persekitaran di Pulau Orang Utan Bukit Merah (BMOUI) dan Zoo Taiping, Perak. Sampel haiwan serta persekitaran yang diperoleh dari kedua-dua kawasan kajian diinokulasi dalam media Ellinghausen-McculloughJohnson-Harris (EMJH) untuk pengkulturan Leptospira. Pengesanan dan pencirian mudah spesies Leptospira melalui PCR dilakukan ke atas kultur serta sampel haiwan yang positif. Pencirian spesies yang lebih mendalam sehingga peringkat serovar menggunakan penjenisan jujukan multi-lokus (MLST) hanya dilakukan ke atas kultur patogenik sahaja. Sebanyak 8/14 kultur daripada sampel persekitaran BMOUI merupakan spesies saprofitik (L. yanagawae, L. meyeri dan L. idonii), 4/14 adalah spesies perantaraan (L. wolffii) dan 2/14 (dilabel sebagai 'Soil2' dan 'BJ3 soil') adalah spesies patogenik. Hasil MLST menunjukkan kultur 'Soil2' telah dikenal pasti sebagai L. interrogans serovar Lai Langkawi dengan nilai penjenisan jujukan, ST: 236. 'BJ3 soil' pula telah diberikan profil alel baharu yang menjana nilai ST baharu iaitu 262 di bawah spesies L. kmetyi. Kesemua 15/15 kultur daripada sampel persekitaran Zoo Taiping merupakan spesies saprofit (L. yanagawae dan L. meyeri). Leptospira yang dikesan secara langsung dalam sampel orang utan dan tikus dari BMOUI berkait rapat dengan spesies L. wolffii. Sampel orang utan dari Zoo Taiping pula berkait rapat dengan spesies L. kmetyi dan L. wolffii. Kajian ini berjaya membuktikan bahawa berlakunya transmisi leptospirosis di BMOUI dan Zoo Taiping yang sememangnya amat penting dalam menambahbaik strategi pencegahan penyakit ini sekaligus membantu dalam usaha pemuliharaan orang utan.
\end{abstract}

Kata kunci: Leptospira; leptospirosis; orang utan; pencirian; roden

\section{ABSTRACT}

Leptospirosis is a bacterial disease caused by Leptospira that infects human and animals. This study was carried out to determine the presence of Leptospira that circulates among orang utans, rodents, and environment in Bukit Merah Orang Utan Island (BMOUI) and Taiping Zoo, Perak. Animal and environmental samples obtained from both study sites were inoculated into Ellinghausen-Mccullough-Johnson-Harris (EMJH) media for leptospiral culturing. Simple detection and characterization of leptospiral species through PCR were conducted on positive cultures and animal samples. Further characterization of leptospiral species up to serovar level via multi-locus sequence typing (MLST) was conducted on pathogenic cultures only. 8/14 isolates from BMOUI environmental samples were known as saprophytic species (L. yanagawae, L. meyeri and L. idonii), 4/14 as intermediate species (L. wolffii) and 2/14 (labelled as 'Soil2' and 'BJ3 soil') as pathogenic leptospires. Through MLST, 'Soil2' was characterized as L. interrogans serovar Lai Langkawi with sequence typing, ST number: 236. Isolate 'BJ3 soil' was given a new set of allelic profiles and ST number of 262 (L. kmetyi). 15/15 environmental cultures from Taiping Zoo were identified as L. yanagawae and L. meyeri. Leptospira in orang utan and rodent samples from BMOUI have shown to be closely related to L. wolffii. Strains detected in orang utan samples from Taiping Zoo were closely related to L. kmetyi and L. wolffii. This study provides evidence on leptospirosis transmission in both locations which can be important for improving strategies in prevention of the disease thus helping in conservation of the orang utans.

Keywords: Characterization; Leptospira; leptospirosis; orang utans; rodents 


\section{PENGENALAN}

Leptospirosis ialah sejenis penyakit zoonotik yang disebabkan oleh bakteria heliks daripada genus Leptospira (Dietrich et al. 2015). Penyakit ini dipercayai telah merebak ke seluruh dunia khususnya di kawasan tropika dan subtropika (Bharti et al. 2003; Dechner 2013; LaRocque et al. 2005; Levett 2001; Slack et al. 2006). Jangkitan Leptospira boleh dikelaskan kepada tiga iaitu asimptomatik (tanpa gejala), sederhana dan teruk. Walaupun jangkitan Leptospira dipercayai kurang merbahaya kepada perumah takungan, namun apabila serovar (antigen khusus yang terdapat pada Leptospira spp.) tidak dapat beradaptasi dengan perumah yang dijangkiti, hal ini akan menyebabkan jangkitan yang lebih serius. Gejala penyakit juga adalah berbeza bergantung pada spesies haiwan yang dijangkiti. Namun, antara gejala umum yang sering dihidapi adalah penyakit ginjal, hati serta kegagalan sistem pembiakan. Bagi manusia yang dijangkiti, antara manifestasi klinikal yang dapat dilihat adalah jaundis, aneroksia, sakit kepala, muntah-muntah, batuk, sakit perut, cirit-birit serta kegagalan buah pinggang (Vijayachari et al. 2008). Transmisi leptospirosis boleh dibahagikan kepada dua iaitu sama ada secara langsung ataupun tidak langsung. Transmisi secara langsung berlaku antara perumah melalui gigitan dan luka yang terdedah di samping sentuhan secara langsung terhadap air kencing atau membran bermukus perumah yang dijangkiti. Transmisi tidak langsung pula berlaku apabila manusia atau haiwan terminum air yang telah dicemari dengan bakteria Leptospira (Dechner 2013; Famatiga 1973).

Leptospirosis telah kembali muncul sebagai penyakit berjangkit yang utama di Malaysia memandangkan berlakunya peningkatan kes jangkitan dan kematian khususnya di sekitar kawasan rekreasi dan rezab hidupan liar (Arif 2013). Sehubungan itu, haiwan liar seperti primat bukan manusia telah dikenali sebagai salah satu perumah Leptospira kerana haiwan ini boleh mendapat jangkitan daripada perumah lain yang berhampiran khususnya tikus (Bengis et al. 2004; Cantu et al. 2008; Kilbourn et al. 2003; Pavlin et al. 2009). Contohnya, monyet probosis dan lutung di Taman Negara Bako, Sarawak telah mendapat jangkitan Leptospira secara langsung melalui tikus dan juga secara tidak langsung melalui air sungai (Jalil 2009). Kajian lepas oleh Thayaparan et al. (2014) juga telah menunjukkan jangkitan leptospirosis dengan bacaan titer yang tinggi $(\geq 1: 400)$ terhadap kera di Pusat Hidupan Liar Matang, Sarawak. Walau bagaimanapun, tiada data epidemiologi leptospirosis dalam primat liar khususnya orang utan di bahagian Semenanjung Malaysia, sekaligus peranan mereka sebagai perumah Leptospira kurang diketahui. Oleh itu, kajian ini dijalankan bagi mengenal pasti jangkitan leptospirosis yang berkitar antara orang utan, roden dan persekitaran di BMOUI dan Zoo Taiping, Perak.

\section{BAHAN DAN KAEDAH}

\section{KAWASAN KAJIAN}

Kajian ini dijalankan di BMOUI dan Zoo Taiping, Perak kerana kedua-dua kawasan ini merupakan pusat konservasi orang utan di Semenanjung Malaysia. Pensampelan dilakukan sebanyak empat kali bermula dari bulan April 2017 sehingga Januari 2018.

\section{SAMPEL KAJIAN}

Sebanyak 30 perangkap roden bersaiz $30 \times 20 \times 20 \mathrm{~cm}$ dipasang secara rawak di sekitar kawasan orang utan di BMOUI dan Zoo Taiping. Roden yang berjaya ditangkap dimatikan menggunakan cecair $30 \% \mathrm{v} / \mathrm{v}$ isofluran dalam propilena glikol sebelum pembedahan dilakukan. Pengenalpastian spesies roden adalah berdasarkan Francis and Barret (2008) yang merujuk kepada beberapa ciri fenotip seperti warna bulu di bahagian sisi, ventral dan dorsal badan, telinga, ekor, kaki belakang serta ukuran panjang dan berat. Sampel darah diambil melalui cucukan jantung dan air kencing (jika ada) diperoleh daripada pundi kencing. Organ dalaman seperti ginjal, limpa dan hati roden juga diambil. Bagi orang utan pula, sampel air kencing diperoleh daripada takungan atas lantai kurungan masing-masing menggunakan picagari dan disimpan ke dalam tiub Falcon $15 \mathrm{~mL}$ yang berlabel. Pensampelan tanah lembap dan air diambil secara rawak di sekitar sangkar dan laluan orang utan menggunakan tiub Falcon $50 \mathrm{~mL}$ berlabel.

Semua sampel haiwan dan persekitaran yang diambil dibawa ke makmal untuk diproses dalam tempoh 12 jam bagi pemencilan Leptospira ke dalam media EMJH. Kesemua kultur dieram secara aerobik dalam inkubator pada suhu $28-30{ }^{\circ} \mathrm{C}$ dan diperiksa di bawah mikroskopi medan gelap dengan selang masa tujuh hari untuk tempoh tiga bulan bagi mengenal pasti kehadiran Leptospira (Benacer et al. 2013). Lebihan sampel air kencing dan organ dalaman haiwan kemudiannya disimpan dalam suhu $-20^{\circ} \mathrm{C}$ untuk ujian molekul selanjutnya.

\section{PENGEKSTRAKAN DNA}

Sampel organ dan air kencing haiwan diekstrak menggunakan QIAamp DNA Mini Kit (Qiagen, Hilden, Germany) berdasarkan arahan pengeluar. Sampel kultur positif Leptospira pula diekstrak menggunakan kaedah pendidihan. Dalam kaedah ini, sebanyak $2 \mathrm{~mL}$ sampel kultur dipelet dengan kelajuan 13000 rcf selama 30 min pada suhu $4{ }^{\circ} \mathrm{C}$, dicuci dua kali dengan $1 \mathrm{~mL}$ PBS dan diampaikan semula dalam $150 \mu \mathrm{L}$ penimbal TrisEDTA (TE) sebelum dididih pada suhu $100{ }^{\circ} \mathrm{C}$ selama tujuh min. Kuantifikasi DNA oleh Thermo Scientific ${ }^{\mathrm{TM}}$ NanoDrop ${ }^{\mathrm{TM}}$ spektrofotometer kemudiannya dilakukan bagi menganggarkan kepekatan DNA dengan lebih 
tepat. Setiap sampel DNA yang telah diekstrak disimpan pada suhu $-20^{\circ} \mathrm{C}$ bagi mengelakkan berlakunya proses degredasi (Baust 2008).

\section{PENGESANAN DAN PENCIRIAN Leptospira spp. DALAM KULTUR POSITIF}

Selain pemerhatian morfologi, pengesanan genus Leptospira daripada bakteria yang dikultur melalui kaedah molekul juga dilakukan. Primer gen $16 \mathrm{~S}$ rRNA (F: GGCGGCGCGTCTTAAACATG, R: GTCCGCCTACGCACCCTTTACG) digunakan dalam PCR kerana kebolehan primer ini dalam mengesan semua jenis Leptospira sama ada spesies patogenik mahupun saprofitik (Djadid et al. 2009). Tindak balas PCR dilakukan dalam jumlah isi padu $25 \mu \mathrm{L}$ yang mengandungi $1 \times$ penimbal $\mathrm{PCR}, 1.5 \mathrm{mM} \mathrm{MgCl}, 0.2$ $\mathrm{mM}$ dNTPs, $0.5 \mu \mathrm{M}$ primer, $0.05 \mathrm{U}$ Taq DNA polymerase (Qiagen, Hilden, Germany) dan 40-60 ng templat DNA. Profil kitaran PCR terdiri daripada pra-denaturasi pada suhu $94{ }^{\circ} \mathrm{C}$ selama 3 min, 35 kitaran untuk suhu $94{ }^{\circ} \mathrm{C}(1$ min) (denaturasi), $54{ }^{\circ} \mathrm{C}(1 \mathrm{~min})$ (penyepuhan $), 72{ }^{\circ} \mathrm{C}(2$ min) (pemanjangan) serta paca-pemanjangan pada suhu 72 ${ }^{\circ} \mathrm{C}$ selama 10 min. Semua produk PCR dianalisis melalui elektroforesis gel agaros berkepekatan 1.5\%. Saiz hasil produk teramplifikasi dianggar dengan membandingkan jalur DNA dengan jalur penanda tetangga $100 \mathrm{pb}$ (1st BASE Biochemicals). Produk DNA yang teramplifikasi daripada primer 16S rRNA dihantar ke Syarikat 1st BASE Sdn Bhd., Malaysia untuk penjujukan DNA. Hasil penjujukan DNA kemudiannya dijajarkan menggunakan perisian Molecular Evolutionary Genetic Analysis Versi 7 (MEGA 7) melalui Muscle sebelum dibandingkan dengan pangkalan data GenBank menggunakan algoritma BLAST yang boleh didapati di laman web http://www. ncbi.nih.gov.

Pencirian jujukan multi-lokus hanya dilakukan ke atas pencilan patogenik bagi menciri Leptospira berdasarkan skema yang menyasarkan tujuh lokus ( $g \operatorname{lm} U$, pntA, sucA, tpiA, pfkB, mreA dan caiB) daripada tujuh spesies Leptospira patogenik (L. alexanderi, $L$. borgpetersenii, L. interrogans, L. kirschneri, L. noguchii, L. santarosai dan L. weilii) (Boonsilp et al. 2013). Tindak balas PCR dilakukan dalam jumlah isi padu $25 \mu \mathrm{L}$ yang mengandungi $1 \times$ penimbal $\mathrm{PCR}, 1.5 \mathrm{mM} \mathrm{MgCl}_{2}, 0.2$ $\mathrm{mM}$ dNTPs, $0.5 \mu \mathrm{M}$ primer, $0.05 \mathrm{U}$ Taq DNA polymerase (Qiagen, Hilden, Germany) dan 40-60 ng templat DNA. Profil kitaran PCR terdiri daripada pra-denaturasi pada suhu $94{ }^{\circ} \mathrm{C}$ selama 3 min, 35 kitaran untuk suhu $94{ }^{\circ} \mathrm{C}(1$ min) (denaturasi), 49.2-56.8 ${ }^{\circ} \mathrm{C}$ (1 min) (penyepuhan), 72 ${ }^{\circ} \mathrm{C}$ (2 min) (pemanjangan) serta paca-pemanjangan pada suhu $72{ }^{\circ} \mathrm{C}$ selama $10 \mathrm{~min}$. Semua produk PCR dianalisis melalui elektroforesis gel agaros berkepekatan $1.5 \%$ dan hasil yang teramplifikasi daripada ketujuh-tujuh primer dihantar ke syarikat 1st BASE Sdn Bhd., Malaysia untuk penjujukan DNA. Hasil penjujukan DNA kemudiannya dipotong dan dijajarkan bersama jujukan rujukan yang diperoleh daripada pangkalan data pubMLST (https:// pubmlst.org/leptospira/) menggunakan perisian MEGA 7 melalui Muscle. Jujukan yang telah dijajarkan ini dibandingkan dengan pangkalan data pubMLST untuk mendapatkan tujuh profil alel $(g \operatorname{lm} U, p n t A, s u c A, t p i A$, $p f k B$, mre $A$ dan $c a i B)$. Gabungan tujuh profil alel ini menghasilkan nilai ST yang kemudiannya dibandingkan dengan pangkalan data pubMLST untuk pencirian Leptospira spp.

PENGESANAN DAN PENCIRIAN Leptospira spp. DALAM SAMPEL HAIWAN (KULTUR NEGATIF)

Bagi mengesan dan menciri Leptospira dalam sampel haiwan, primer gen $r r s 2$ (F-CATGCAAGTCAAGCGGAGTA, R-GCATCGAGAGGAATTAACATCA) (Ahmed et al. 2006) digunakan. Tindak balas PCR dilakukan dalam jumlah isi padu $25 \mu \mathrm{L}$ yang mengandungi $1 \times$ penimbal PCR, 1.5 $\mathrm{mM} \mathrm{MgCl}, 0.2 \mathrm{mM}$ dNTPs, $0.5 \mu \mathrm{M}$ primer, $0.05 \mathrm{U}$ Taq DNA polymerase (Qiagen, Hilden, Germany) dan 4060 ng templat DNA. Profil kitaran PCR terdiri daripada pra-denaturasi pada suhu $94{ }^{\circ} \mathrm{C}$ selama 3 min, 35 kitaran untuk suhu $94{ }^{\circ} \mathrm{C}(1 \mathrm{~min})$ (denaturasi), $54{ }^{\circ} \mathrm{C}(1 \mathrm{~min})$ (penyepuhan), $72{ }^{\circ} \mathrm{C}$ (2 min) (pemanjangan) serta pacapemanjangan pada suhu $72{ }^{\circ} \mathrm{C}$ selama $10 \mathrm{~min}$. Semua produk PCR dianalisis melalui elektroforesis gel agaros berkepekatan $1.5 \%$ dan hasil yang teramplifikasi daripada primer $r r s 2$ dihantar ke Syarikat 1st BASE, Sdn Bhd., Malaysia untuk penjujukan DNA. Hasil penjujukan DNA kemudiannya dijajarkan menggunakan perisian MEGA 7 melalui Muscle sebelum dibandingkan dengan pangkalan data GenBank menggunakan algoritma BLAST.

\section{ANALISIS DATA DAN STATISTIK}

Pohon filogeni berdasarkan kaedah hubungan jiran dengan butstrap 1000 dibangunkan berdasarkan semua jujukan sampel yang telah dijajarkan bersama jujukan rujukan melalui Clustal W menggunakan perisian MEGA 7.

\section{ETIKA KAJIAN}

Kajian ini telah diluluskan oleh Jabatan PERHILITAN dengan permit khas: B-00245-16-17, Jawatankuasa Etika Haiwan UKM (UKMAEC): FST/2016/HANI/25JAN./822-JAN.-2017-JUNE-2018 dan Jawatankuasa Etika Manusia UKM: UKM/PPI/111/8/JEP-2017-243. 
HASIL DAN PERBINCANGAN

PENGESANAN DAN PENCIRIAN Leptospira spp. DALAM KULTUR POSITIF MELALUI GEN 16S RRNA

Sebanyak 14/87 kultur Leptospira yang dipencilkan daripada sampel tanah BMOUI serta 8/36 kultur daripada sampel tanah Zoo Taiping dan 7/37 kultur daripada sampel air Zoo Taiping telah berjaya mengamplifikasi gen 16S rRNA dengan saiz jalur 454 pb (Rajah 1).

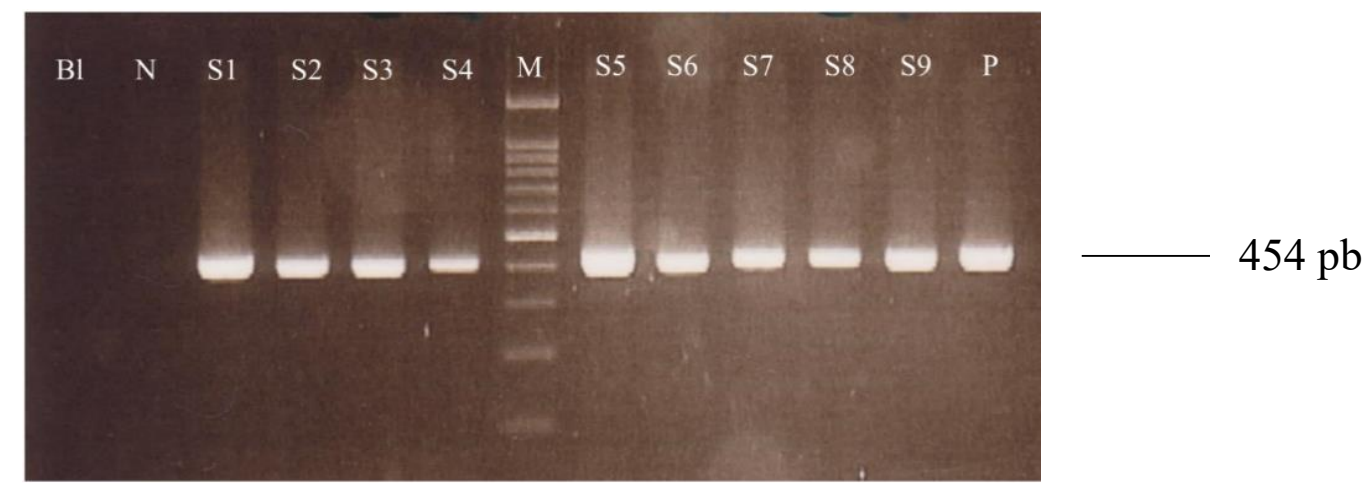

RAJAH 1. Contoh beberapa kultur Leptospira daripada sampel tanah BMOUI dan Zoo Taiping yang berjaya mengamplifikasi gen $16 \mathrm{~S}$ rRNA. Sampel kultur dianggap positif Leptospira apabila menghasilkan jalur sebaris dengan kawalan positif (P) pada saiz $454 \mathrm{pb}$. Telaga 1: Blank (Bl), telaga

2: kawalan negatif $(\mathrm{N})$, telaga 3-6: kultur Leptospira dari tanah BMOUI, telaga 7: penanda (M), telaga 8-12: kultur Leptospira dari tanah Zoo Taiping dan telaga 13: kawalan positif (P)

Pohon filogeni berdasarkan kaedah hubungan jiran dengan nilai butstrap 1000 telah mengelaskan jujukan teramplifikasi gen $16 \mathrm{~S} r R N A$ dan jujukan rujukan kepada tiga klad yang berbeza iaitu spesies saprofitik, perantaraan dan patogenik (Rajah 2).

Semua sampel persekitaran Zoo Taiping, 15/15 kultur merupakan spesies saprofitik iaitu L. yanagawae dan L. meyeri dengan jarak genetik antara spesies adalah 0.00 (Rajah 2). Bagi sampel persekitaran BMOUI pula, sebanyak 8/14 kultur tanah telah dikenal pasti sebagai spesies saprofitik iaitu $L$. yanagawae, L. meyeri dan $L$. idonii dengan jarak genetik antara spesies adalah 0.000.02 (Rajah 2). Kajian lepas oleh Saito et al. (2013) dan Scialfa et al. (2017) juga menunjukkan sampel sekitaran di kawasan kajian masing-masing didominasi oleh spesies L. yanagawae and L. meyeri berdasarkan analisis filogeni $16 \mathrm{~S} r R N A$. Hal ini adalah kerana kebolehan spesies saprofitik yang hidup bebas di persekitaran tanpa memerlukan sebarang perumah menyebabkan bakteria jenis ini boleh dijumpai dengan banyak di tanah lembap dan air. Tambahan pula, iklim di negara ini yang panas dan lembap sepanjang tahun juga menyumbang kepada keadaan yang kondusif untuk kemandirian Leptospira pada persekitaran (Benacer et al. 2016). Namun, kajian oleh Chiani et al. (2016) telah melaporkan L. meyeri juga berjaya dikesan dalam sampel klinikal meskipun kejangkitan dan kepatogenannya masih tidak jelas.

Selain itu, sebanyak empat kultur tanah BMOUI telah dikenal pasti sebagai spesies perantaraan iaitu L. wolffii dengan jarak genetik antara spesies adalah dalam lingkungan 0.00-0.01 manakala hanya dua pencilan sahaja diperoleh daripada sampel tanah BMOUI dikenal pasti sebagai Leptospira patogenik (Rajah 2). Strain 'Soil2' terletak berhampiran dengan spesies $L$. interrogans manakala strain 'BJ3 soil' pula dengan $L$. kmetyi dengan masing-masing mempunyai jarak genetik antara spesies sebanyak 0.00. Bilangan Leptospira patogenik yang dijumpai adalah sedikit berbanding saprofitik kerana spesies ini kurang beradaptasi terhadap kondisi persekitaran berbanding spesies saprofitik dan memerlukan perumah untuk membiak serta bermandiri (Barragan et al. 2011). 


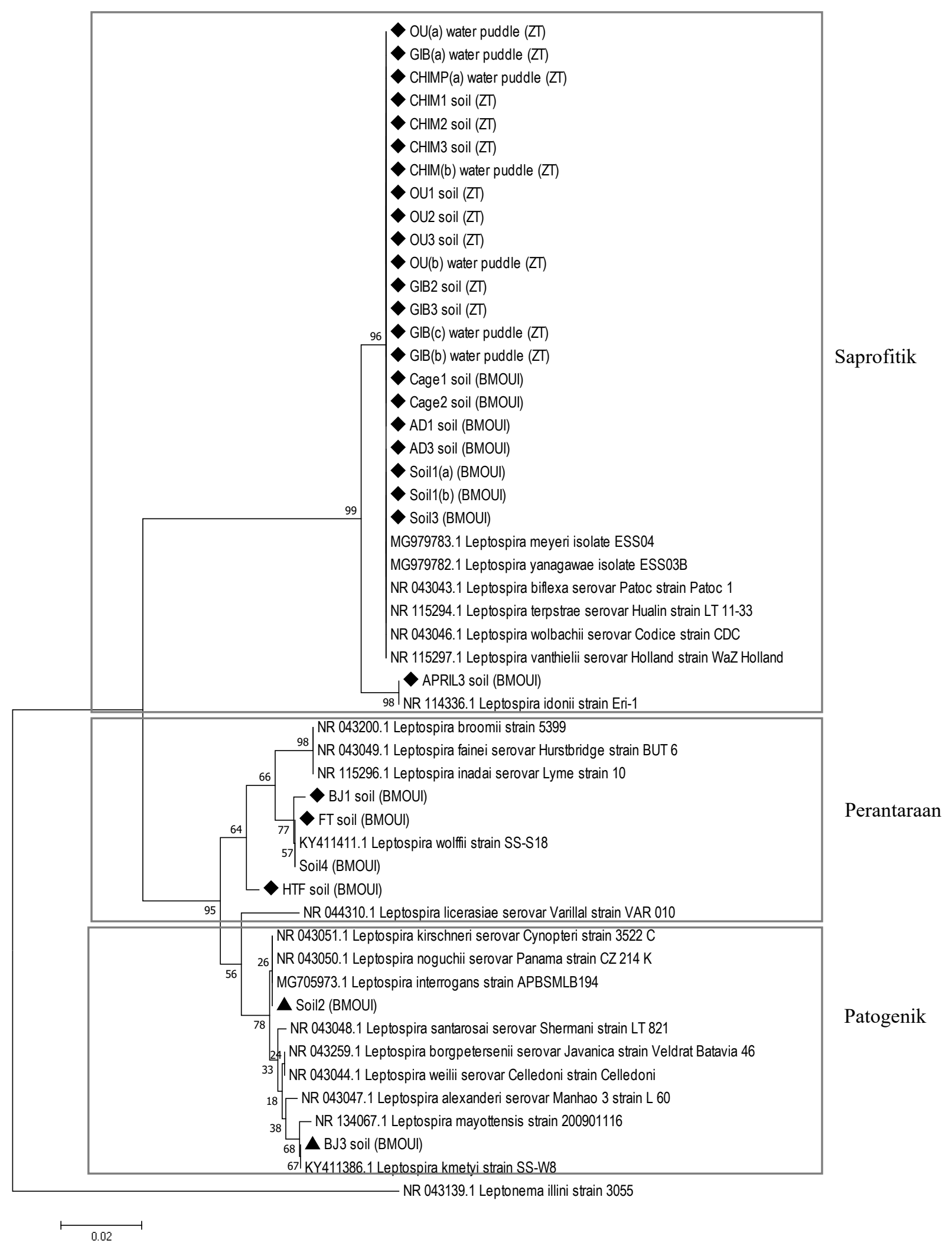

RAJAH 2. Pohon filogeni berdasarkan kaedah hubungan jiran dengan butstrap 1000 yang dibangunkan daripada jujukan gen 16S rRNA dan jujukan rujukan NCBI. Jujukan Leptonema illini pula digunakan sebagai kumpulan luar. Kultur dari BMOUI dan Zoo Taiping (ZT) ditandakan dengan $\bullet$. Penjenisan jujukan multi-lokus (MLST) dijalankan pada sampel yang bertanda $\boldsymbol{\Lambda}$. Bar skala menandakan penggantian nukleotida bagi setiap tapak. ' Water puddle' = lopak air/takungan air; soil $=$ tanah 
PENCIRIAN KULTUR Leptospira spp. PATOGENIK MELALUI MLST

Hasil keputusan MLST yang dilakukan ke atas kultur patogenik 'Soil2' menunjukkan pencilan ini berjaya mengamplifikasi lima daripada tujuh gen penyelenggara (berdasarkan skema 1) dan perbandingan lima jujukan tersebut dengan pangkalan data pubMLST telah menjana profil alel separa lengkap (pntA: 71, sucA: 1, tpiA: 13, $m r e A$ : 3, caiB: 6). Hasil daripada gabungan profil alel ini, spesies L. interrogans serovar Lai Langkawi (nilai ST: 236) merupakan padanan terdekat dengan pencilan 'Soil2'. Berdasarkan kajian lepas, terdapat seekor orang utan BMOUI telah menunjukkan tindak balas terhadap serovar Lai Langkawi dalam ujian darah yang dilakukan (Nadia et al. 2019). Hal ini menandakan orang utan tersebut telah menghasilkan antibodi terhadap serovar ini disebabkan pendedahan berterusan dengan tanah tercemar di kawasan sekitarnya. Serovar Lai juga merupakan punca utama jangkitan penyakit leptospirosis dalam kalangan pelancong yang terlibat dalam aktiviti eko-pelancongan di Malaysia (Sejvar et al. 2003).

Pencilan patogenik 'BJ3 soil' pula tidak dapat dibandingkan dengan pangkalan data pubMLST kerana setiap jujukannya adalah tidak sepadan dan mempunyai perbezaan besar dengan jujukan rujukan. Oleh itu, pencilan ini telah diberi profil alel baharu yang lengkap $(\mathrm{g} \operatorname{lm} U: 70$, pntA: 79, sucA: 75, tpiA: 69,pfkB: 96, mreA: 73, caiB: 64) dan didaftarkan dalam pangkalan data pubMLST sebagai pencilan baharu. Gabungan profil alel ini menjana nilai ST baharu iaitu 262 di bawah spesies L. kmetyi. Menurut Mohd Ali et al. (2018), L. kmetyi merupakan strain yang paling banyak dipencilkan daripada tanah di kawasan tempat tinggal pesakit leptospirosis di Kelantan dan Terengganu.

PENGESANAN DAN PENCIRIAN Leptospira spp. PADA SAMPEL HAIWAN (KULTUR NEGATIF) MELALUI GEN RRS2 Kaedah pencirian Leptospira secara langsung terhadap sampel haiwan dilakukan kerana bakteria ini tidak berjaya dipencilkan melalui pengkulturan dalam media EMJH. Hal ini adalah kerana Leptospira khususnya spesies patogenik merupakan mikroorganisma sensitif. Menurut Boonsilp et al. (2011), haiwan tersebut mungkin dijangkiti dengan pencilan yang gagal untuk bermandiri dalam medium kultur yang biasa digunakan dalam makmal dan keadaan semula jadi lebih menyokong kemandirian bakteria ini. Hasilnya, beberapa sampel menunjukkan jangkitan tisu renal yang positif oleh bakteria ini melalui pengamplifikasian gen $r r s 2$.

Sebanyak 1/23 sampel ginjal tikus ('T12') dan 1/12 sampel air kencing orang utan 'Harry' dari BMOUI berjaya mengamplifikasi gen rrs 2 dengan saiz jalur $452 \mathrm{pb}$. Berdasarkan pohon filogeni yang dibangunkan, kedudukan strain ini adalah berhampiran dengan spesies $L$. wolffii strain UPM-K.Bharu 4 dengan jarak antara spesies sebanyak 0.000-0.002 (Rajah 3). Memandangkan L. wolffii telah dijumpai dalam sampel tanah (Rajah 2) serta sampel haiwan (Rajah 3) dari BMOUI, hal ini menunjukkan transmisi $L$. wolffii kepada sesetengah orang utan berlaku secara langsung daripada tikus yang dijangkiti serta tidak langsung melalui tanah yang tercemar. Jung et al. (2007) berpendapat bahawa tikus liar yang membawa Leptospira merupakan punca utama haiwan lain dalam kurungan mendapat jangkitan memandangkan tikus sahaja mampu bergerak bebas sekaligus menyebarkan bakteria Leptospira di kawasan yang dilawati. Menurut pengendali haiwan di BMOUI dan Zoo Taiping, tikus seringkali dilihat berkeliaran di sekitar kawasan orang utan dan kurungan mereka serta di tempat penyimpanan stok makanan haiwan. Tambahan pula, tikus merupakan sumber jangkitan bagi kes leptospirosis yang melibatkan 52 ekor monyet (Cebus albifrons, C. capuchins dan $C$. apella) yang dibela dalam kurungan di pusat rehabilitasi hidupan liar Colombia (Szonyi et al. 2011).

Bagi sampel dari Zoo Taiping pula, sebanyak 2/5 sampel air kencing orang utan ('Veera' dan 'Pudin') merupakan positif bagi gen rrs2. Kedudukan sampel 'Veera' dalam pohon filogeni adalah berhampiran dengan spesies L. kmetyi serovar Malaysia dengan jarak antara spesies bersamaan dengan 0.004 (Rajah 3). Sampel 'Pudin' pula adalah berhampiran dengan spesies $L$. wolffii strain UPM-K.Bharu 4 dengan jarak antara spesies adalah sebanyak 0.000 (Rajah 3). Walau bagaimanapun, oleh kerana semua pencilan daripada sampel persekitaran Zoo Taiping merupakan spesies saprofitik (Rajah 2), orang utan yang menunjukkan keputusan positif terhadap Leptospira patogenik dan perantaraan berkemungkinan mendapat jangkitan secara langsung melalui sesama perumah takungan.

Dalam kajian ini, kultur positif kebanyakannya terdiri daripada spesies saprofitik. Oleh itu, gen rrs2 tidak digunakan dalam analisis filogeni kultur positif disebabkan oleh hanyutan jujukan yang rendah. Hal ini masih menjadi persoalan sama ada gen ini dapat memberikan sasaran yang optimum untuk membezakan antara Leptospira patogenik dan saprofitik (Ahmed et al. 2006; Haake et al. 2000). Walau bagaimanapun, primer gen $r r s 2$ masih digunakan untuk pengesanan dan pencirian spesies patogenik dan perantaraan kerana $r r s 2$ merupakan rantau 452-nukleotida pada gen $16 \mathrm{~S} r R N A$ yang juga dikenali sebagai salah satu gen penyelenggara dalam MLST skema 3 (Ahmed et al. 2011). Pencirian lengkap MLST (berdasarkan penyasaran 7 gen penyelenggara) sehingga ke peringkat serovar tidak dapat dilakukan ke atas Leptospira patogenik dan perantaraan dalam sampel haiwan kerana kuantiti DNA yang amat sedikit. Oleh itu, pengesanan dan pencirian spesies melalui penyasaran $r r s 2$ adalah memadai. Hal ini disokong oleh kajian Boonsilp et al. (2011) yang juga menyasarkan gen rrs2 untuk mengesan dan menciri Leptospira patogenik daripada sampel darah pesakit Thailand yang tidak berjaya dikultur. 


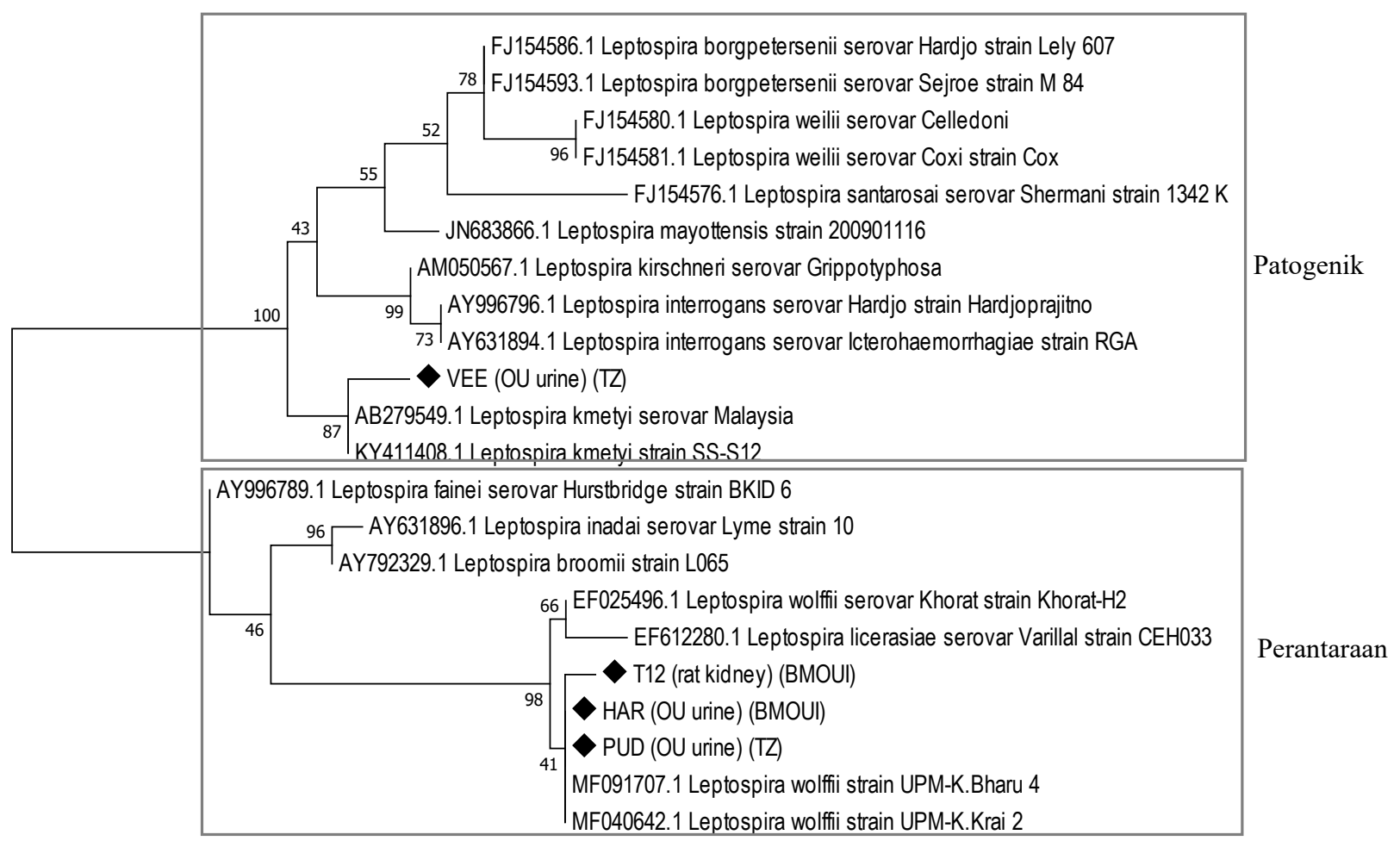

$\stackrel{\longmapsto}{0.005}$

RAJAH 3. Pohon filogeni berdasarkan kaedah hubungan jiran dengan butstrap 1000 yang dibangunkan daripada jujukan gen rrs 2 dan jujukan rujukan NCBI. Kultur dari BMOUI dan Zoo Taiping (ZT) ditandakan dengan $\bullet$. Bar skala menandakan penggantian nukleotida bagi setiap tapak. 'OU urine' = air kencing orang utan; 'rat kidney' = ginjal tikus; VEE = Veera; HAR $=$ Harry; PUD $=$ Pudin

\section{KESIMPULAN}

Persekitaran kawasan BMOUI dan Zoo Taiping masingmasing didominasi oleh kehadiran spesies Leptospira saprofitik kerana kebolehannya bermandiri di luar perumah. Walau bagaimanapun, perumah takungan seperti tikus dan orang utan di kedua-dua kawasan merupakan pembawa Leptospira patogenik dan perantaraan. Meskipun bilangan perumah yang dijangkiti adalah sedikit, namun interaksi/sentuhan sesama perumah haiwan boleh menyebabkan jangkitan baharu kepada perumah yang lain. Selain sentuhan secara langsung, transmisi Leptospira boleh berlaku melalui air kencing perumah takungan yang positif menyebabkan tanah dan air di sekitarnya tercemar dengan kehadiran bakteria ini. Hal ini dapat dilihat pada sampel tanah BMOUI yang positif dengan kehadiran beberapa strain Leptospira patogenik dan perantaraan. Oleh itu, langkah kawalan seperti menjaga kebersihan habitat orang utan dan sumber air mereka harus dipertingkatkan untuk mengurangkan jangkitan positif. Tempat yang berpotensi menjadi sarang tikus hendaklah dimusnahkan bagi mengawal populasi tikus. Selain itu, orang utan di kedua-dua kawasan kajian perlu menjalani ujian saringan leptospirosis secara berkala sebelum dibebaskan ke habitat asal bagi mengelakkan transmisi kepada hidupan liar yang lain.

\section{PENGHARGAAN}

Projek penyelidikan ini dibiayai oleh geran GUP-2016021. Sekalung penghargaan diucapkan kepada Dr. Fairuz Amran, Ketua Jabatan Unit Bakteriologi Institut Penyelidikan Perubatan (IMR) kerana menyediakan kemudahan makmal untuk kajian ini. Kami juga ingin mengucapkan jutaan terima kasih kepada kakitangan IMR yang sudi berkongsi ilmu dan memberi bantuan teknikal sepanjang kajian ini dijalankan. Ribuan terima kasih juga diucapkan kepada Pengarah BMOUI serta Zoo Taiping kerana memberi kebenaran kepada kami untuk mengendalikan projek ini di kawasan pemuliharaan orang utan. Setinggi-tinggi penghargaan juga diucapkan kepada Dr. Sabapathy Dharmalingam dan Dr. Muhamad 
Ridhwan Affendi serta pengendali haiwan lain yang turut terlibat secara langsung mahupun tidak langsung sepanjang kajian ini dijalankan.

\section{RUJUKAN}

Ahmed, A., Thaipadungpanit, J., Boonsilp, S., Wuthiekanun, V., Nalam, K., Spratt, B.G., Aaensen, D.M., Smythe, L.D., Ahmed, N., Feil, E.J., Hartskeerl, R.A. \& Peacock, S.J. 2011. Comparison of two multilocus sequence based genotyping schemes for Leptospira species. PLoS Neglected Tropical Diseases 5(11): e1374.

Ahmed, N., Manjulata Devi, S., De los Á Valverde, M., Vijayachari, P., Machang'u, R.S., Ellis, W.A. \& Hartskeerl, R.A. 2006. Multilocus sequence typing method for identification and genotypic classification of pathogenic Leptospira species. Annals of Clinical Microbiology and Antimicrobials 5(1): 28.

Arif, M.T. 2013. Changing nature of health crisis from infectious diseases and responses over three decades in Malaysia. Borneo Journal of Resource Science and Technology 2(2): $1-11$.

Barragan, V.A., Mejia, M.E., Trávez, A., Zapata, S., Hartskeerl, R.A., Haake, D.A. \& Trueba, G.A. 2011. Interactions of Leptospira with environmental bacteria from surface water. Current Microbiology 62(6): 1802-1806.

Baust, J.G. 2008. Strategies for the storage of DNA. Cell Preservation Technology 6(4): 251-252.

Benacer, D., Thong, K.L., Verasahib, K.B., Galloway, R.L., Hartskeerl, R.A., Lewis, J.W. \& Mohd Zain, S.N. 2016. Human leptospirosis in Malaysia: Reviewing the challenges after 8 decades (1925-2012). Asia-Pacific Journal of Public Health 28(4): 290-302.

Benacer, D., Siti Nursheena, M.Z., Fairuz, A., Galloway, R.L. \& Thong, K.L. 2013. Isolation and molecular characterization of Leptospira interrogans and Leptospira borgpetersenii isolates from the urban rat population of Kuala Lumpur, Malaysia. The American Society of Tropical Medical and Hygiene 88(4): 704-709.

Bengis, R., Leighton, F., Fischer, J., Artois, M., Morner, T. $\&$ Tate, C. 2004. The role of wildlife in emerging and reemerging zoonoses. Scientific and Technical Review 23(2): 497-512.

Bharti, A.R., Nally, J.E., Ricaldi, J.N., Matthias, M.A., Diaz, M.M., Lovett, M.A., Levett, P.N., Gilman, R.H., Willig, M.R., Gotuzzo, E. \& Vinetz, J.M. 2003. Leptospirosis: A zoonotic disease of global importance. The Lancet Infectious Diseases 3(12): 757-771.

Boonsilp, S., Thaipadungpanit, J., Amornchai, P., Wuthiekanun, V., Bailey, M.S., Holden, M.T.G., Zhang, C., Jiang, X., Koizumi, N., Taylor, K., Galloway, R., Hoffmaster, A.R., Craig, S., Smythe, L.D., Hartskeerl, R.A., Day, N.P., Chantratita, N., Feil, E.J., Aanensen, D.M., Spratt, B.G. \& Peacock, S.J. 2013. A single multilocus sequence typing (MLST) scheme for seven pathogenic Leptospira species. PLoS Neglected Tropical Diseases 7(1): e1954.

Boonsilp, S., Thaipadungpanit, J., Amornchai, P., Wuthiekanun, V., Chierakul, W., Limmathurotsakul, D., Day, N.P. \& Peacock, S.J. 2011. Molecular detection and speciation of pathogenic Leptospira spp. in blood from patients with culture-negatif leptospirosis. BMC Infectious Diseases 11(1): 338

Cantu, A., Ortega-S, J.A., Mosqueda, J., Garcia-Vazquez, Z., Henke, S. \& George, J. 2008. Prevalence of infectious agents in free-ranging white-tailed deer in northeastern Mexico. Journal of Wildlife Diseases 44(4): 1002-1007.

Chiani, Y., Jacob, P., Varni, V., Lamdolt, N., Schmeling, M.F., Pujato, N., Caimi, K. \& Vanasco, B. 2016. Isolation and clinical sample typing of human leptospirosis cases in Argentina. Infection, Genetics and Evolution 37(2016): 245-251.

Dechner, A. 2013. A retrospective analysis of the leptospirosis research in Columbia. Journal of Infection in Developing Countries 8(3): 258-264.

Dietrich, M., Muhdorfer, K., Tortosa, P. \& Markotter, W. 2015. Leptospira and bats: Story of an emerging friendship. PLOS Pathogens 11(11): e1005176.

Djadid, N.D., Ganji, Z.F., Gouya, M.M., Rezvani, M. \& Zakeri, S. 2009. A simple and rapid nested polymerase chain reactionrestriction fragment length polymorphism technique for differentiation of pathogenic and nonpathogenic Leptospira spp. Diagnostic Microbiology and Infectious Disease 63(3): 251-256.

Famatiga, E.G. 1973. Leptospirosis in Philippine monkeys. The Southeast Asian Journal of Tropical Medicine and Public Health 4(3): 316-318.

Francis, C.M. \& Barrett, P. 2008. Guide to the Mammals of Southeast Asia. Princeton: Princeton University Press. pp. $1-392$.

Haake, D.A., Chao, G., Zuerner, R.L., Barnett, J.K., Barnett, D., Mazel, M., Matsunaga, J., Levett, P.N. \& Bolin, C.A. 2000. The leptospiral major outer membrane protein LipL32 is a lipoprotein expressed during mammalian infection. Infection and Immunity 68(4): 2276-2285.

Jalil, M.F.B. 2009. Comparative phylogeography of three primate species in the Lower Kinabatangan Wildlife Sanctuary, Sabah, Malaysia. PhD Thesis. Cardiff University, UK (Unpublised).

Jung, B.Y., Choi, J.S., Kim, K.T., Song, Y.K., Lee, S.H., Lee, K.W., Kim, J.Y. \& Moon, O.K. 2007. Seroprevalence of leptospirosis in Korean municipal zoo animals. Journal of Veterinary Medical Science 69(8): 861-863.

Kilbourn, A.M., Karesh, W.B., Wolfe, N.D., Bosi, E.J., Cook, R.A. \& Andau, M. 2003. Health evaluation of free-ranging and semi-captive orang utans (Pongo pygmaeus pygmaeus) in Sabah, Malaysia. Journal of Wildlife Diseases 39(1): 73-83.

LaRocque, R.C., Breiman, R.F., Ari, M.D., Morey, R.E., Janan, F.A., Hayes, J.M., Hossain, M.A., Brooks, W.A. \& Levett, P.N. 2005. Leptospirosis during dengue outbreak, Bangladesh. Emerging Infectious Diseases Journal 11(5): 766-769.

Levett, P.N. 2001. Leptospirosis. Clinical Microbiology Reviews 14(2001): 296-326.

Mohd Ali, M.R., Mohammad Safiee, A.W., Yusof, N.Y., Fauzi, M.H., Yean, C.Y. \& Ismail, N. 2018. Isolation of Leptospira kmetyi from residential areas of patients with leptospirosis in Kelantan, Malaysia. Journal of Infection and Public Health 11(2018): 578-580. 
Nadia, A.S., Md-Zain, B.M., Dharmalingam, S., Fairuz, A. \& Hani-Kartini, A. 2019. Serological survey of leptospirosis in high-risk rangers and wild animals from ex-situ captive centers. Tropical Biomedicine 36(2): 443-452.

Pavlin, B.I., Schloegel, L.M. \& Daszak, P. 2009. Risk of importing zoonotic diseases through wildlife trade, United States. Emerging Infectious Diseases Journal 15(11): 17211726.

Scialfa, E., Grune, S., Brihuega, B., Aguirre, P. \& Rivero, M. 2017. Isolation of saprophytic Leptospira spp. from a selected environmental water source of Argentina. Revista Argentina de Microbiología 50(3): 323-326.

Saito, M., Villanueva, S., Chakraborty, A., Miyahara, S., Segawa, T., Asoh, T., Ozuru, R., Gloriani, N.G., Yanagihara, Y. \& Yoshida, S. 2013. Comparative analysis of Leptospira strains isolated from environmental soil and water in the Philippines and Japan. Applied and Environmental Microbiology 79(2): 601-609.

Sejvar, J., Bancroft, E., Winthrop, K., Bettinger, J., Bajani, M., Bragg, S., Shutt, K., Kaiser, R., Marano, N., Popovic, T., Tappero, J.W., Ashford, D., Mascola, L., Vugia, D., Perkins, B., Rosenstein, N. \& the Eco-Challenge Investigation Team. 2003. Leptospirosis in "Eco-Challenge" athletes, Malaysian Borneo, 2000. Emerging Infectious Diseases 9(6): 702-707.

Slack, A.T., Symonds, M.L., Dohnt, M.F. \& Smythe, L.D. 2006. The epidemiology of leptospirosis and the emergence of Leptospira borgpetersenii serovar Arborea in Queensland, Australia, 1998-2004. Epidemiology and Infection 134(6): 1217-1225.

Szonyi, B., Agudelo-Flórez, P., Ramírez, M., Moreno, N. \& Ko, A.I. 2011. An outbreak of severe leptospirosis in capuchin (Cebus) monkeys. Veterinary Journal 2188(2): 237-239.
Thayaparan, S., Robertson, I.D. \& Abdullah, M.T. 2014 Leptospiral agglutinins in captive and free ranging nonhuman primates in Sarawak, Malaysia. Veterinary World 7(6): 428-431.

Vijayachari, P.I., Sugunan, A.P. \& Shriram, A.N. 2008 Leptospirosis: An emerging global public health problem. Journal of Biosciences 33(4): 557-569.

Nadia Aqilla Shamsusah \& Hani-Kartini Agustar*

Pusat Sains Bumi dan Alam Sekitar

Universiti Kebangsaan Malaysia

43600 UKM Bangi, Selangor Darul Ehsan

Malaysia

Badrul Munir Md Zain

Pusat Integratif Biologi

Universiti Kebangsaan Malaysia

43600 UKM Bangi, Selangor Darul Ehsan

Malaysia

Sabapathy Dharmalingam

Yayasan Pulau Orang Utan Bukit Merah

34400 Semanggol, Perak Darul Ridzuan

Malaysia

Fairuz Amran

Jabatan Bakteriologi

Institut Penyelidikan Perubatan

50588 Kuala Lumpur, Wilayah Persekutuan

Malaysia

*Pengarang untuk surat-menyurat; email: hani_ag@ukm.edu.my

Diserahkan: 18 Julai 2019

Diterima: 24 Jun 2020 